NBER WORKING PAPER SERIES

IMPUTING CORPORATE TAX LIABILITIES

TO INDIVIDUAL TAXPAYERS

Martin Feldstein

Working Paper No. 2349

NATIONAL BUREAU OF ECONOMIC RESEARCH

1050 Massachusetts Avenue

Cambridge, MA 02138

August 1987

The research reported here is part of the NBER's research program in Taxation and project in Government Budget. Any opinions expressed are those of the author and not those of the National Bureau of Economic Research. 
NBER Working Paper \#2349

August 1987

\section{Imputing Corporate Tax Liabilities to Individual Taxpayers}

\section{ABSTRACT}

This paper presents a method of studying the distributional consequences of corporate tax changes by imputing to individual tax returns the net effect of changes in effective corporate tax rates. Particular attention is given to the difference between nominal and real capital income, to the problem of corporate pension funds, and to the automatic effect of corporate tax changes on dividends and retained earnings.

Application of this imputation method to the tax changes enacted in 1986 shows that the actual distribution of the total tax change was very different from the traditional distribution of only the personal income tax change. The net imputed corporate tax increase was equivalent to a rise of 6 percentage points in the personal income tax among taxpayers with 1988 incomes over $\$ 200,000$ and 4 percentage points among taxpayers with incomes between $\$ 100,000$ and $\$ 200,000$. The corporate income tax increase also added the equivalent of an 8 percent rise in the income tax for taxpayers with incomes between $\$ 10,000$ and $\$ 20,000$. By contrast, for middle income taxpayers (with incomes between $\$ 30,000$ and $\$ 75,000$ ) the corporate tax increase was equivalent to an income tax $r$ ise of only 1 or 2 percent. The analysis shows that the higher corporate tax represents a particularly large increase for taxpayers over the age of 65 ; on average, tax returns with at least one taxpayer over age 65 will pay 12 percent more tax under the 1986 tax legislation than they would otherwise have paid.

Distributional considerations will continue to play a large role in the public and Congressional discussions of future tax reforms. The present study shows that it is very important to include the distributional consequences of corporate as well as personal tax changes in the analys is of any proposed tax reforms.

Martin Feldstein

National Bureau of Economic Research 1050 Massachusetts Avenue

Cambridge, MA 02138 


\title{
Imputing Corporate Tax Liabilities to Individual Taxpayers
}

\author{
Martin Feldstein*
}

The distributional consequences of any proposed tax change are always a central focus of attention and debate among policy officials and the general public. The staffs of the Treasury and the Congressional Joint Committee on Taxation use microeconomic simulation models based on individual tax return data to calculate the effect of any proposed change on the distribution of average tax burdens by income class, the numbers of gainers and losers in each income class, etc. A major shortcoming of such analyses, however, is that they always focus exclusively on the changes in the personal income tax. The distributional consequences of changes in the corporate income tax are completely ignored. 1

The 1986 tax reform provides a clear example of the importance of ignoring corporate tax changes in analyzing the distributional consequences of tax reform. The intended effect of the tax reform is to raise corporate income tax liabilities by approximately $\$ 25$ billion a year and to reduce individual tax liabilities by an equal amount. Although the distribution of the proposed personal tax changes was a primary concern of the legislators as they modified tax rates and tax rules; no attention was given to the distributional consequences of the change in corporate taxation. This procedure had the anomalous (and politically convenient) implication that the individuals at each income level were projected to receive a tax reduction even though the tax bill as a whole was designed to be revenue neutral. As the analysis of the present paper indicates, including the changes in the 
corporate income tax as well as the changes in the personal income tax results in a very different picture of the distributional consequences of the 1986 tax bill.

There has been surprisingly little attention in the public finance literature to the problem of imputing the corporate income tax to individual taxpayers in order to evaluate the distributional consequences of alternative corporate tax rules. Neither the Treasury nor the staff of the Joint Committee on Taxation ever includes corporate tax changes in calculating the distributional consequences of proposed tax legislation. Some private analysts (e.g., Pechman, 1985; Browning and Johnson, 1979) have reflected the corporate income tax in assessing the distribution of current tax burdens but, as explained below, there are a number of serious problems with the methods that they use. Other private analysts have made no attempt to reflect corporate tax changes when evaluating the effects of past tax law changes on the taxes paid by households at different income levels (e.g., Ott and Dittrich, 1981).

There has, of course, been no shortage of sophisticated analysis of the more general problem of the incidence of the corporate income tax between capital and labor. Ever since Harberger (1962), economists have recognized that the incidence question is a problem in general equilibrium analysis. Subsequent work has shown how this general equilibrium approach can be made computational with a quite disaggregated and dynamic economic model; see, e.g., Shoven and whalley (1972) and Kotlikoff and Summers (1986). The general equilibrium problem of tax incidence can also be extended to a portfolio approach that explicitly incorporates the effects of taxation on the net riskiness of different assets (see Feldstein and slemrod (1980)). 
No attempt will be made in the current paper to contribute to this general analysis of corporate tax incidence. Nor will the present analysis try to reflect the complex industry-specific characteristics of the 1986 Tax Reform Act that distinguish it from a general across-the-board increase in corporate tax liabilities. Instead, the focus will be on the technical problems of imputing an assumed or calculated increase in the tax on capital income to a representative sample of individual tax returns that can then be aggregated by income class (or other attributes) to calculate the distributional consequences of the change in capital income taxation.

One interpretation of the current analysis is that it shows how to impute to individuals an increase in the corporate income tax on the assumption that 100 percent of the corporate tax increase is borne by capital and that all capital bears that tax increase equally. This assumption is the basic conclusion of Harberger (1962) for a two-sector economy in which the elasticities of substitution between capital and labor are the same in both sectors and equal to the elasticity of substitution between the two goods in consumption. Harberger argues that the conclusion is at least approximately valid under a wider range of conditions and it is probably true that this has become the conventional wisdom among most public finance specialists. Feldstein and slemrod (1980) show that the introduction of risk and a portfolio framework for analyzing tax incidence does not alter the conclusion that an.increase in the corporate income tax would be borne exclusively by capital income under Harberger's elasticity assumptions even though in the Feldstein-slemrod portfolio framework the expected rates of return are not the same in all sectors and the change in tax does not affect all types of capital income equaliy. 
Those who do not believe that a change in the corporate income tax is borne exclusively by the owners of capital can interpret the current paper as analyzing the question of how any given increase in the tax on capital income in general is distributed among individuals. For example, if the corporate income tax is assumed to be borne half by capital and half by labor, the current analysis indicates how the half borne by capital should be imputed to individual taxpayers.

The analysis uses the NBER TAXSIM model to calculate changes in individual tax liabilities. TAXSIM is a computer model that incorporates a large stratified random sample of individual tax returns provided by the Internal Revenue Service and a computer program that can calculate the tax liability for each individual tax return for a variety of alternative tax rules and alternative assumptions about tax incidence or taxpayer behavior. The TAXSIM model used in the present paper incorporates 30,723 individual tax returns for 1983, a 25 percent random sample of the stratified random sample provided by the Internal Revenue Service.

Each tax return has been modified to make the sample an estimate of the population of taxpayers in 1988. This involves modifying each dollar amount in the tax return to an estimated 1988 level and reweighting the sample to reflect the likely growth in the number of tax returns during that interval. The 1988 individual income tax liability for each tax return is then calculated using the tax rules and tax rates enacted by Congress in September 1986. This serves as a base to which the corporate tax liabilities and the change in corporate tax liabilities can be added.

Section 1 of this paper comments on the methods used by previous analysts to impute corporate income tax liabilities. The next four sections then 
discuss the key issues involved in using information from the national income and product accounts and the flow of funds accounts to impute corporate tax changes to individual tax returns. The emphas is throughout is on finding methods that can actually be implemented with available data.

The analysis is used in Sections 6 and 7 to impute to individual tax returns the estimated 1988 corporate tax liability under the pre-1987 tax law and the effect of the increase in corporate tax liabilities embodied in the 1986 legislation. These imputations are then used to compare the conventionally measured changes in personal tax liabilities with the changes in the combined personal and corporate tax liabilities.

\section{Previous Methods of Imputing Corporate Tax Burdens}

Although the analyses of the Treasury and of the Joint Committee on Taxation do not impute corporate income tax changes to individual taxpayers, several academic studies have presented such calculations. The work of Pechman (1985) is perhaps the most fully developed and widely used of these calculations. 2 It is useful therefore to start with Pechman's work and then to comment on the work of other economists who have made imputations in order to assess the distributional consequences of changes in corporate taxation.

Pechman emphasizes the uncertain incidence of the corporate income tax and therefore presents imputations based on alternative assumptions about how the incidence of the corporate income tax is divided among dividends, property income in general, employees' compensation, and consumption. Although my concern in the present paper is not with this general problem of 
tax incidence, some comments on the incidence assumptions underlying Pechman's more detailed imputation calculations is appropriate in the current context.

It is difficult to see the rationale for allocating any portion of the corporate tax burden on the basis of each taxpayer's total consumption. Since no attempt is made to distinguish between the consumption of corporate and noncorporate goods, allocation in proportion to consumption is essentially equivalent to allocating in proportion to the labor and capital incomes that finance that consumption. As such, it is redundant to have an imputation based on an allocation that attributes some fraction of the corporate tax burden to labor income, some portion to capital income and the remainder to consumption.

Any allocation based on total consumption must ultimately rest on some notion that the corporate income tax is embodied in the price of the product and therefore borne by consumers. Since the theory of incidence is essentially a theory of relative prices and factor rewards, this notion of forward shifting only makes sense if it is assumed that an increase in the corporate tax is accompanied by a change in monetary policy that permits the overall price level to increase. Even if it is accepted that a rise in the corporate income tax leads to an increase in the price level, it is difficult to see why this should be analyzed as a tax on consumers rather than as a reduction in real wages and real capità income.

To justify an imputation on the basis of consumption, it might be argued that the propensity to consume is not the same at all income levels and that the higher prices affect income that is consumed but not income that is saved. Such an argument would be fallacious because the savings are merely postponed 
consumption and therefore should be assigned tax on the same basis as current consumption.

A second possible argument for imputing a corporate tax increase on the basis of consumption rather than capital and labor incomes is that a significant fraction of all consumption is now financed by Social Security and other government transfer payments rather than by factor earnings. If an increase in the corporation tax causes the overall price level to rise, recipients of transfer payments would ceteris paribus see their real incomes fall. Such an analysis is misleading because Social Security benefits are explicitly indexed to the level of consumer prices while other types of transfer payments are likely to be adjusted by Congress in response to a rise in the price level.

In short, it seems best to analyze the change in the corporate income tax as a change in real factor incomes and not to be confused by a possible change in the price level.

Pechman's allocation on the basis of dividends and of property income in general is central to the analysis of the current paper. The assumption that the tax rests more heavily on dividends than on other types of capital income implies that net of tax rates of return to portfolio investors are not the same in the corporate and noncorporate sectors. Although an assumption of unequal net rates of return is unusual in conventional general equilibrium incidence analysis, it is consistent with a portfolio model of tax incidence of the type developed in Feldstein and slemrod (1980). However, in such a portfolio model, an increase in the corporate tax reduces the riskiness as well as the yield on corporate securities. With a wide class of utility functions, 
the combination of lower risk and lower yield increases the demand for corpcrate securities. The reduced net income does not adequately measure the effect of the tax on the different types of capital income because the reduced risk of corporate equity is a significant compensation for the reduced yield. On balance, it is very difficult to know how to interpret an incidence assumption that assigns a greater reduction in net yield to corporate equity than to other types of capital income.

My concern in the current paper is not, however, with the inappropriateness of using consumption or dividends as a base for imputing the corporate income tax. Rather it is with the technical problems involved in imputing to individual taxpayers the corporate tax liabilities that are assumed to be borne by capital income in general. The method used by Pechman for allocating the portion of the tax that he assumes is borne by capital income in general begins by redefining the capital income of each individual taxpayer by imputing retained earnings on the basis of that individual's dividend income. An estimate of the accrued capital gain in noncorporate assets (changes in the value of business inventories, of farm assets and of nonfarm real estate) is also imputed to each tax return. The capital income received by nonprofit institutions and by pension funds is explicitly ignored. The proportion of the corporate income tax that is assumed to be borne by capital income in general is then imputed to individual tax returns on the basis of each return's net-of-tax total capital income.

There are several serious problems with this method. First, it is wrong to exclude the capital income received by pension funds. The vast bulk of these funds are the assets of defined benefit plans. 3 The retirement benefits 
received by retirees and by current employees who participate in a defined benefit plan do not depend on changes in the rate of return earned by the assets of the pension plan. Variations in the return on plan assets inure to the benefit (or detriment) of the corporations that sponsor the defined benefit plans since a rise in the net income of the plan permits the corporate sponsor to reduce its contributions while a fall in the plan's net rate of return requires the corporate sponsor to increase its contributions. With benefits independent of plan assets, the corporate tax borne by the capital income received by defined benefit pension funds is actually borne by the sponsoring corporations and should be allocated to individuals on the basis of their ownership of those corporations. 4 For the minority of pension funds that are of the defined contribution type, the individual pension plan participants would bear the increase in the corporate tax. Since pension assets are now more than 1.7 trillion dollars, excluding their share of the corporate tax burden is a serious omission.

A second important problem with the method of Pechman and others is that it does not distinguish between real capital income and nominal capital income. The basic theory of incidence tells us that the rate of return is equal on all types of capital and that an increase in the corporate income tax reduces real income in proportion to the real capital income of each taxpayer. This has several important implications. Net interest income must be redefined as real interest income. The retained earnings that are imputed to individual taxpayers should be the real retained earnings of corporations, defined in a way that reflects the inventory valuation adjustment, the capital consumption adjustment and the inflation-induced erosion of the net corporate 
debt. The imputation of changes in the value of inventories, farm assets and nonfarm real estate should be purged of their inflation component. When that is done, the remaining year to year fluctuations in asset values are only transitory changes that should not be included in the definition of capital income for the current purpose.

A third issue is that an increase in the tax paid by corporations automatically reduces dividends and other types of income taxable at the personal level. To the extent that dividends are reduced, shareholders pay less personal tax. To the extent that retained earnings are reduced, accrued capital gains decline and subsequent personal capital gains taxes fall. These automatic reductions in personal tax payments offset in part the higher corporate tax burden imputed to these individuals. These changes in personal tax burdens must be reflected in the calculations of the distribution of the changes in total tax burdens.

Finally, it is not clear what justification there is for Pechman's procedure allocating the general tax on capital income on the basis of the net-of-persona1-tax capital income rather than on the pre-persona1-tax capital income. Conventional incidence analysis would say that two individuals with the same capital assets would bear the same amount of the corporate income tax regardless of any difference in their personal tax rates. Pechman's method would apparently give an individual in the 50 percent personal tax bracket only two-thirds of the corporate tax burden assigned to an individual in the 25 percent tax bracket even though both individuals owned the same amount of capital assets.

I have discussed the method of Pechman and his collaborators because it has produced some of the most important and often-cited figures on the 
distribution of tax burdens and effective tax rates. It is clear however from these criticisms that the Pechman method may be seriously misleading.

The shortcomings of the Pechman method are not avoided in the other studies of the distribution of tax liabilities. Browning and Johnson (1975) also fail to distinguish between real and nominal capital income, disregard the capital income of pension plans, and do not reflect the fact that increased corporate tax liabilities lower the personal tax base.

Although there are other studies of the distribution of the corporate tax liabilities, 5 none of these deals with the problems raised here in a satisfactory way. The remainder of the present paper is an attempt to improve on the current methods.

\section{Imputation of a Tax on Capital Income: A First Approximation}

It is useful to begin by ignoring the issues of corporate pensions, inflation adjustments and the second-round response of dividends and capital gains. With these simplifying assumptions, imputing a change in capital taxation involves three calculations. First, the total capital income attributable to individuals in a base year must be calculated. The calculations in this paper use 1985, the most recent year for which national income data are now available. Second, this must be extrapolated to 1988, the year for which the tax increase is to be analyzed. Finally, a rule must be adopted for imputing corporate retained earnings to individual tax returns.

\subsection{Total Attributable Capital Income}

The most recent National Income and Product Accounts (as of July 1986) estimate that total corporate profits before tax, with the inventory 
valuations adjustment (IVA) and the capital consumption adjustment (CCA), were $\$ 280.7$ billion in 1985 . This figure includes $\$ 16.8$ billion of "profits" made by the Federal Reserve Bank. When these are excluded, the total private corporate profits before tax are $\$ 263.9$ billion. Further adjustments in this figure will be made in subsequent sections but this $\$ 263.9$ billion will represent total pre-tax profits for the present section.

The relevant concept of interest income for our current purpose is the net interest income of persons. The national income accounts indicate 1985 personal interest income of $\$ 476.2$ billion. Against this must be offset the \$145.1 billion interest paid on mortgages and the other personal interest paid to business of $\$ 82.6$ billion. The net interest income of households is therefore $\$ 248.5$ billion. Subsequent sections will adjust this for the effects of inflation and for the fraction of "individual" interest income that actually goes to private pensions.

A third component of the capital income of individuals is rental income. The national income accounts estimate the 1985 net rental income of individuals as $\$ 7.6$ billion (with the capital consumption adjustment), including the imputed rental income on owner-occupied housing. Any rental income of corporations is treated as part of corporate profits. Since this net rental income is net of the $\$ 145.1$ billion of mortgage interest that has already been subtracted in calculating net interest income, that amount must be added back to calculate the proper rental figure (and to avoid subtracting the interest paid twice): the relevant rental income amount is therefore $\$ 152.7$ billion.

There is a final remaining category of individual income that represents a mixture of labor income and capital income: proprietors' incomes in farm 
and nonfarm establishments. Approximately ninety percent of the $\$ 254$ billion of proprietors' income is attributed by the Commerce Department to nonfarm establishments. These include professional practices (law, medicine, dentistry, etc.), smal1 unincorporated service businesses (restaurants, drycleaning firms, etc.), and other types of establishments with very low capital requirements relative to their labor costs. It is difficult to estimate what fraction of the total proprietor's income should be classified as capital income and even more difficult to impute this relative small amount to individual tax returns. The present analysis makes the simplifying assumption of ignoring the capital income in these establishments. 6

\subsection{Extrapolation to 1988}

The three categories of capital income received by individuals either directly or as corporate shareholders -- private corporate profits, net interest, and rental income -- totaled $\$ 665.1$ billion in 1985 . This total must be extrapolated to 1988 in a way that is at least approximately consistent with the Treasury's estimate of the corporate tax liability under the old and new tax laws. The items that appear on the personal income tax form must also be extrapolated in a comparable way.

This extrapolation from 1985 to 1988 is based on the mid-year review forecasts prepared by the Reagan administration in August 1986 (Executive Office of the President, 1986). Unfortunately, the published detail is not adequate to permit a full item-by-item extrapolation of the 1985 income and expenses to 1988. Instead, the present analysis follows the August 1986 offical mid-year review and assumes that aggregate corporate profits and 
dividends rise by 59.6 percent between 1985 and 1988 and that aggregate interest and rental income income increases by 16.6 percent. The implied 1988 total private pretax capital income is $\$ 889.0$ billion. The individual tax return items in the TAXSIM return are first extrapolated from 1983 (the year of the actual tax returns) to 1985 (the most recent year for which national account data are available) on the basis of the observed changes in aggregate figures and the assumption that the number of tax returns increases by 1.9 percent per year. These 1985 figures are then extrapolated to 1988 by using the mid-year review forecasts of the administration. 7

The estimated corporate income tax in 1988 and the corresponding proposed increase is based on the published projections of the Treasury. These published Treasury projections are for fiscal years rather than the calendar years needed for integration with the individual income tax simulations. Adjusting from fiscal to calender years implies an estimate of approximately \$95 billion of "baseline" 1988 corporate tax revenue under the pre-reform tax law and an increase of $\$ 25$ billion due to the tax reform.

\subsection{Imputing the Corporate Income Tax to Individuals}

The projected $\$ 95$ billion corporate tax liability for 1988 is equivalent to 10.7 cents of tax liability per dollar of the $\$ 889.0$ billion of total private pretax capital income. This figure, which is the increase in the effective tax rate on all capital income caused by the corporate income tax, will be central in imputing the baseline old-law corporate tax liability. Subtracting the $\$ 95$ billion baseline tax liability from the projected $\$ 889$ billion total pretax capital income implies a total net capital income of 
$\$ 794$ billion net of the baseline corporate tax but before the personal tax. The $\$ 25$ billion projected increase in the corporate income tax is equal to 3.1 cents per dollar of this net capital income. Imputing the $\$ 25$ billion increase in the corporate income tax is equivalent to assigning this tax rise of 3.1 cents per dollar of total net capital income to each individual taxpayer.

Note that this method implies that the baseline corporate income tax is allocated among individuals on the assumption that in the absence of the corporate income tax all forms of capital income would have the same rate of return and that the corporate income tax reduces that rate of return equally on all types of investments. The imputation of the increase in the corporate income tax therefore starts with the assumption that the net-of-corporate tax return to corporate equity is the same as the return to debt and to real property. 8

Although a tax of 10.7 cents can be imputed per dollar of capital income in general and of interest income in particular, the tax to be imputed per dollar of dividend income must be adjusted to reflect the tax borne by the associated retained earnings. The national income accounts indicate that in 1985 dividends were $\$ 81.6$ billion and pretax corporate profits were $\$ 263.9$ billion. Extrapolating these to 1988 yields dividends of $\$ 130.2$ billion and pretax private corporate profits of $\$ 421.2$ billion. Thus in imputing the tax to individual returns on the basis of dividends, each dollar of dividends represents $\$ 3.23$ of pretax corporate profits. Similarly, each dollar of dividend income represents $\$ 2.50$ of post-corporate-tax corporate profits. These figures can be used to allocate the corporate tax liabilities on the basis of the dividend income reported on individual tax returns. 
More specifically, since the $\$ 95$ billion of corporate tax liability under current law is equivalent to 10.7 cents per dollar of pretax capital income, the tax borne by corporate equity capital is equivalent to $0.107 \times \$ 3.23=$ 0.346 dollars of tax liability per dollar of dividend income. Moreover, since the $\$ 25$ billion tax increase is equivalent to 3.1 cents per dollar of corporate profits net of the corporate income tax, the proposed increase in corporate tax liabilities that is borne by corporate equity is equivalent to $0.031 \times \$ 2.50=0.078$ dollars of increased tax liability per dollar of dividend income.

These calculations, summarized in column 1 of Table 1, provide the figures required for the "first approximation" imputation of the $\$ 95$ billion baseline current-law corporate tax liability in 1988 and of the $\$ 25$ billion increase in the tax on capital income. To represent the baseline corporate tax, for each individual tax return in the TAXSIM mode1, a tax of 34.6 cents would be imputed per dollar of dividend and 10.7 cents per dollar of net interest and of rental income. 9 similarly, the "first approximation" imputation of the $\$ 25$ billion corporate tax increase requires imputing a tax of 7.8 cents per dollar of dividend income and a tax of 3.1 cents per do 1 lar of net interest income and net rental income.

Although this would provide the basis for a "first approximation" imputation of the corporate tax, I will not pursue these figures but turn instead to developing an imputation that deals more appropriately with pensions, inflation and the automated response of dividends to corporate tax liabilities. 


\section{The Income of Corporate Pension Plans}

The national income accounts treat corporate pension plans as part of the household sector. As such, the dividends and interest received by corporate pension plans are treated as if they are received by individuals. Since that income is not taxable, the method of imputation described in section 2 essentially ignores the tax burden that falls on the capital income of these pension plans. This is equivalent to assuming that the pensions do bear their proportionate share of the increased tax on capital income but that it is not assignable to any individuals.

As I noted in Section 1, this procedure, which is explicitly adopted by Pechman (1985), is not appropriate. The correct procedure depends on the nature of the pension plan. In a defined contribution plan, employers make prescribed annual contributions but the employees' ultimate level of benefits depends on the yield earned on the accumulated plan assets. The TIAA-CREF plan and other plans used at most academic institutions are defined contribution plans. In a defined benefit plan, employers promise a specific retirement benefit (typically related to years of service and earnings in final years before retirement); fluctuations in the yield on the pension assets influence the amount that the employers have to contribute to finance those promised benefits but do not affect the level of benefits that employees receive. 10

The taxes borne by the assets of defined contribution plans should be imputed to the employees for whom those assets have been accumulated. Individual retirement accounts, self-employment retirement accounts (Keogh plans) and $401 k$ employee saving plans should all be treated in this same way. 
Unfortunately, no information about any of these assets is available on individual tax returns.

The present analysis will therefore treat all pension assets as if they were the assets of defined benefit plans. Although about two-thirds of total pension assets are in fact in defined benefit plans, 11 this simplification will distort the imputation of the taxes borne by pension assets. It is nevertheless better to treat all pensions as defined benefit plans than to ignore the taxes borne by pension assets.

The tax that is attributable to pension assets in defined benefit plans is thus assumed here to be borne by the corporate sponsor of those plans. To impute this to individual taxpayers, the calculations of Section 2 must be modified by increasing the private corporate profits by the amount of the interest income attributable to the pension assets and by modifying the amount of retained earnings per dollar of dividends actually received by individuals.

More specifically, in 1985 private pension plans received $\$ 11.2$ billion of dividends and $\$ 51.8$ billion of interest. 12 The dividend income of pension funds is already counted as part of total private corporate profits. To estimate adjusted corporate profits, it is therefore only necessary to add the $\$ 51.8$ billion of interest to the previously calculated $\$ 263.9$ billion profits to obtain adjusted corporate profits of $\$ 315.7$ billion. In addition, the dividend income of individuals is reduced by $\$ 11.2$ billion (from $\$ 81.6$ billion to $\$ 70.4$ billion) and the net interest income is reduced by $\$ 51.8$ billion (from $\$ 248.5$ billion to $\$ 196.7$ billion).

Extrapolating these amounts to 1988 implies total capital income of $\$ 911.2$ billion, adjusted corporate profits of $\$ 503.9$ billion and personal 
dividends of $\$ 112.4$ billion. Based on these figures, the $\$ 95$ billion of baseline corporate income tax is equivalent to 10.4 cents per dollar of pretax capital income and the $\$ 25$ billion 1988 tax increase is equivalent to a tax increase of 3.1 cents per dollar of net capital income.

The reduction in "personal dividend income" (i.e., dividends not paid to corporations or to pension plans) raises both the baseline tax per dollar of true personal dividend income and the tax increase per dollar of true dividend income. The adjustments imply that there are $\$ 503.9$ billion of corporate profits and $\$ 112.4$ billion of adjusted dividends or $\$ 4.48$ of adjusted private pretax corporate profits per dollar of personal dividends. Similarly, adjusted net-of-tax private corporate profits are $\$ 503.9$ billion minus $\$ 95$ billion or $\$ 408.9$ billion, implying $\$ 3.64$ of net profit per dollar of dividends.

With a baseline corporate tax of 10.4 cents per dollar of total capital income, the implied tax burden attributable on the basis of personal dividends received is $10.4 \times 4.48=46.6$ cents of baseline corporate tax per dollar of personal dividend income. Similarly, with a $\$ 25$ billion tax increase corresponding to 3.1 cents of additional tax per dollar of capital income, the tax burden per dollar of dividends received by individuals rises by 3.1 cents $\times 3.64=11.3$ cents per dollar of dividends instead of the 7.8 cents reported in the previous section. These figures are summarized in column 2 of Table 1. 
(1)

With
First
Approximation

Billions of 1988 Dollars
(3) With Pension Imputation and Inflation Ad justment

(1) Total pretax private capital income

889.0

911.2

707.5

(2) Baseline corporate tax liability

95.0

95.0

95.0

(3) Total baseline net private capital income

794.0

816.2

612.5

(4) Projected corporate tax increase

25.0

25.0

25.0

(5) Pretax corporate profits

421.2

503.9

498.6

(6) Personal dividends

130.2

112.4

112.4

Dollars

(A) Baseline tax per dollar of total pretax capital income $[(2) \div(1)]$

0.107

0.104

0.134

(B) Corporate tax increase per dollar of baseline net capital income $[(4) \div(3)]$

0.031

0.031

0.041

(C) Pretax corporate profits per dollar of dividends $[(6) \div(5)]$

3.23

4.48

4.44

(D) Corporate profits net of baseline tax per dollar of dividends $[(6) \div\{(5)-(2)\}]$

2.50

3.64

3.59

(E) Baseline corporate tax per dollar of dividends $[(A) \times(C)]$

0.346

0.466

0.594

(F) Corporate tax increase per dollar of dividends $[(B) \times(D)]$

0.078

0.113

0.147

See text for more complete definitions and for description of methods of calculation. All figures refer to 1988 projection. 


\section{Inflation Adjustments and Real Capital Income}

The calculations of Sections 2 and 3 , as well as the imputations presented by all previous researchers, fail to distinguish between real capital income and nominal capital income. More specifically, although the capital consumption adjustments make the profit and rent estimates reflect inflation-adjusted depreciation, the interest income and expenses are nominal amounts. Since the theory of incidence clearly requires the calculations to be done in terms of real capital incomes, the past procedure is incorrect. It distorts the measurement not only of the net interest income of individual taxpayers but also of corporate profits (by overstating net interest costs) and of pension income (by overstating interest income).

The present section shows how to correct the different components of interest income and expenses for inflation in order to obtain a more appropriate imputation of changes in capital income. Consider first the interest income and expenses of the household sector. 13 The interest income can be converted from a nominal amount to the corresponding real amount by multiplying the nominal interest income by the ratio of the effective real interest rate to the nominal interest rate implicit in the reported interest income. The implicit nominal interest rate can be estimated on the basis of the composition of the household sector's taxable interest bearing assets.14 The Flow of Funds tables report that in 1985 the household sector held 61.8 percent of these assets in traditional savings accounts, small time deposits or NOW accounts, 15.6 percent in money market mutual funds or in other forms that would pay a short-term market rate of interest, 7.9 percent in long-term corporate bonds and $\mathbf{1 4 . 7}$ percent in long-term government bonds; no attempt has 
been made to reflect differences in the composition of these assets among income classes.

In 1985, the yield on short-term money market accounts (represented by the six month commercial paper rate) was $\mathbf{8 . 0}$ percent. Corporate Baa bonds had a yield of 12.7 percent while government 10 year bonds had a yield of 10.6 percent. The typical rate on traditional savings accounts was five percent. When these interest rates are combined using the portfolio weights described in the previous paragraph, the nominal interest rate on household taxable interest bearing assets was 6.9 percent.

Since the consumer price index rose 3.7 percent between December 1984 and December 1985 , the corresponding real interest rate was $(1.069 / 1.037)-1=$ 0.03 .15 This implies that the ratio of the real interest rate to the nominal interest income in 1985 was $0.031 / 0.069=0.45$. This is the factor that is used to convert nominal interest income to real interest income. It implies that the nominal personal interest income of $\$ 476.2$ billion in 1985 corresponds to real interest income of only $\$ 214.3$ billion.

A corresponding calculation must be done to convert the nominal personal interest payments to business into a real amount. The Flow of Funds accounts indicate that 63.3 percent of the personal debt consists of nonfarm mortgages, 27.7 percent is consumer credit and the remaining 9.0 percent is a miscellaneous collection that includes loans, trade credit and unpaid insurance premiums. The interest rate for outstanding home mortgages, taken to be an average of the new home mortgage rates for each of the past 15 years, 16 was 10.4 percent for 1985 . The interest rate on consumer credit in 1985 is assumed to average 18 percent. Finally, the remaining category of 
loans and other personal liabilities is taken to carry an interest rate equal to 2 percent over the prime rate or 12 percent. The combined average rate of interest on the personal debt including mortgage debt was therefore 12.6 percent.

Applying the 3.7 percent rate of inflation in the same way here as applied to nominal interest rates on household interest bearing assets implies that the real pretax interest rate on household debt was 8.5 percent and therefore that the ratio of the real interest yield to the nominal coupon interest rate on household sector debt in 1985 was 0.67 . Applying this factor to the $\$ 227.7$ billion of interest that individuals paid to businesses and on mortgages in 1985 implies a corresponding real interest expense of on ly $\$ 152.6$ bil1ion.

Combining the estimated real interest income and real interest expenses for 1985 implies that the net interest income of the household sector in 1984 was not the $\$ 248.3$ billion used in the previous sections but only $\$ 61.7$ billion.

An inflation correction also changes the estimated value of the interest income of corporate pensions. Since the fixed income assets of pensions are generally long-term securities (bonds and mortgages), it is reasonable to estimate the nominal yield on these securities as the rate on Baa corporate bonds, 12.7 percent. With an inflation rate of 3.7 percent, only 68 percent of the interest income of pensions was real interest income. Applying this ratio to the interest income of pension funds implies that their real interest income was not the $\$ 51.8$ billion reported in the previous section but only $\$ 35.2$ billion. Subtracting this from $\$ 61.7$ billion of total household net 
real interest income leaves $\$ 26.5$ billion of net real interest income received by individuals.

Finally there is the problem of adjusting corporate profits for the inflationary effects on nominal corporate assets and liabilities. The IVA and CCA already adjust inventory gains and depreciation for changes in the price level. The immediately previous paragraph describes how pension interest income that is included in the adjusted corporate profits must be decreased. What remains to be taken into account is the inflation erosion of the corporate debt.17 The inflation erosion of the corporate net debt is estimated for this purpose as 0.037 times the net fixed-income liabilities of the corporate sector measured at market value.18 The estimated net debt erosion of $\$ 13.3$ is then added to the previously measured corporate profits.

With the adjustments described in this section and the previous ones, the final estimate of the adjusted pretax corporate profits for 1985 becomes:

(1) the private corporate profits with the IVA and CCA, $\$ 263.9 ;$ plus (2) $\$ 35.2$ billion of inflation adjusted interest income received by corporate pension plans; plus (3) $\$ 13.3$ billion of decline in the market value of corporate debt caused by inflation. The total adjusted real corporate profits is thus $\$ 312.4$ in 1985 .

Adding to this the $\$ 152.7$ billion net rental income of the household sector (which is already adjusted for inflation) and the $\$ 26.5$ billion net real interest income of individuals yields a total adjusted real capital income of $\$ 491.6$ billion for 1985 .

Extrapolating these real income figures to 1988 implies total real capital income of $\$ 707.5$ billion, real adjusted corporate profits of $\$ 498.6$ 
billion and real net interest income of $\$ 30.9$ billion. 1988 dividends remain unchanged from the previous section at \$112.4 billion.

These figures, summarized in column 3 of Table 1, imply that the baseline $\$ 95$ billion tax is equivalent to 13.4 cents per dollar of real capital income. Since there are $\$ 4.44$ of profits per dollar of dividends, the baseline corporate tax burden on shareholders is equivalent to 59.4 cents per dollar of dividends $(13.4 \times 4.44)$.

Similarly, since net capital income is $\$ 612.5$ billion (i.e., $\$ 707.5$ billion minus $\$ 95$ billion of $\operatorname{tax})$, the $\$ 25$ billion tax increase is equivalent to 4.1 cents per dollar of net capital income. With $\$ 3.59$ of net profits per dollar of dividends, the corporate tax increase on shareholders is equivalent to 14.7 cents per dollar of dividends $(4.1 \times 3.59)$.

Before looking at the implications of these adjustments for the distribution of the increased tax burden, the next section considers a final problem: the response of dividends and retained earnings to the increase in the corporate tax.

\section{Automatic Changes in Taxable Personal Income}

A rise in corporate tax payments automatically reduces taxable personal income. To the extent that the higher corporate tax payments are borne by corporate capital, firms must reduce dividends or retained earnings or both. Whatever the response, it implies an automatic reduction in the personal taxes paid by individuals. A reduction in dividends reduces personal taxable income directly and therefore the personal tax on that income. A reduction in retained earnings lowers the value of the share price and therefore ultimately 
reduces capital gains and the taxes on those gains. To the extent that higher corporate tax payments are borne by other types of capital, they reduce the return on that capital and therefore the corresponding income at the personal level.

The conventional revenue estimation procedure ignores the effect of corporate tax increases on personal tax liabilities and therefore overstates the revenue effect of raising corporate taxes. As the calculations below indicate, the magnitude of this effect can be quite substantial.

To make this adjustment operationa1, the reduction in capital income due to the corporate income tax must be divided between corporate capital income and noncorporate capital income. The simplest assumption, and the one adopted here, is that the gross of tax capital incomes of the corporate and noncorporate sectors remain constant (as they would in the classical Harberger unit elasticity economy), implying that corporate sector net capital income falls by the full amount of the corporate tax. Note that this does not imply that the tax is borne just by corporate shareholders. The rate of return falls by the same amount on all types of capital. But the shift in the capital stock from the corporate sector to the noncorporate sector is just enough (given the assumption of unit elasticities) to maintain the capital income of the noncorporate sector and to reduce the corporate sector capital income by the fu11 amount of the corporate tax.

The decline in corporate sector net income must also be divided between a reduction of dividends and a reduction of retained earnings. Econometric studies of dividend behaviour (e.g., Lintner (1956) and Feldstein (1970)) imply that dividends adjust to net profits gradually but with a long-run 
response that maintains the same ratio of dividends to net earnings unless the changes in tax rules alter the relative cost of dividends and retained earnings. Although the 1986 reduction in marginal personal income tax rates and the accompanying rise in capital gains rates both increase the relative attractiveness of dividends, reflecting the likely corporate response to this change would go beyond the nonbehavioural character of the current analysis. But a reduction of dividends and. retained earnings is forced upon firms by their reduction in net earnings and cannot be ignored even in an analys is that does not attempt to include the response of economic agents to changes in relative prices.

In this spirit, it is appropriate to assume that firms adjust dividends and retained earnings in a way that maintains an unchanged ratio of dividends to real retained earnings. For this purpose, retained earnings must be based on economic profits with the capital consumption adjustment and the inventory valuation adjustment. In addition, these profits must be adjusted by adding the product of the inflation rate and the outstanding net corporate debt. When this calculation is done for each year in the decade from 1976 through 1985, the ratio of dividends to the sum of dividends and adjusted retained earnings is 0.475 .

Dividing the $\$ 95$ billion 1988 baseline corporate tax liability into dividends and retained earnings in this ratio implies that the baseline corporate tax reduces 1988 dividends by $\$ 45.1$ billion and retained earnings by $\$ 49.9$ billion. Similarly, the $\$ 25$ billion rise in corporate tax receipts would reduce dividends by $\$ 11.9$ billion and retained earnings by $\$ 13.1$ billion. 
Since the total projected dividends at the 1988 level are $\$ 112.4$ billion, the preexisting tax reduces dividends at the rate of 40.1 cents per dollar of projected 1988 dividends and reduces retained earnings by 44.4 cents per dollar of projected 1988 dividends. Similarly, the projected $\$ 25$ billion rise in corporate taxes imply that dividends will be reduced by 10.6 cents per dollar of dividends and that retained earnings would be reduced by 11.6 cents per dollar of dividends.

The remaining difficulty in calculating the resulting change in personal tax liabilities is deciding how much tax to associate with the change in retained earnings. There are two issues. Each dollar of retained earnings may raise the share value by less than a dollar (as emphasized by Bradford (1981) and others). Moreover, the delay in realizing capital gains and the pcssibility of avoiding taxable realization altogether by bequeathing the appreciated stock mean that the effective tax rate is less than the statutory rate on capital gains. The calculations in this paper assume that each individual's effective rate of tax on the dollars of retained earnings is equal to one half of that individual's capital gains tax rate.

\section{Imputing the Baseline Corporate Income Tax}

It is now possible to summarize the effects of the $\$ 95$ billion 1988 corporate income tax and to present the simulation results on the effect of that tax on the distribution of tax liabilities.

The calculations that have been presented imply that the $\$ 95$ billion baseline corporate income tax in 1988 has four effects: 
(1) It reduces dividends by 40.1 cents per dollar of dividends reported by individual taxpayers;

(2) It reduces retained earnings by 44.4 cents per dollar of dividends reported by individual taxpayers;

(3) It implies an additional corporate tax liability of 59.4 cents per dollar of dividends; and

(4) It implies an additional corporate tax liability of 13.4 cents per dollar of real interest income.

These estimates are now used in conjunction with the TAXSIM program to calculate the effect of the baseline $\$ 95$ billion corporate tax on each individual in the TAXSIM sample. This analysis calculates two basic measures: the effect of the corporate income tax on personal tax liabilities and the extra imputed burden of the corporate tax.

The calculation of the effect of the corporate income tax on individual tax liabilities starts with a projection of 1988 personal income tax liabilities for each individual in the TAXSIM sample under the tax law enacted in 1986 ("the new tax law"). Recall that, as noted in Section 2.2, for this purpose the TAXSIM sample of tax returns is reweighted to represent the growth in the number of potential tax returns by 1988 and the dollar amounts are rescaled to reflect the projected growth in nominal GNP and its components between 1985 and 1988 . The TAXSIM program contains the rate schedule and tax rules (as far as possible) of the new tax law enacted in 1986.

The effect of the corporate tax on personal income tax liabilities is calculated by adding to each individual's reported dividend income an amount 
equal to 40.1 cents per dollar of reported dividend income and to each individual's long-term capital gain an amount equal to 44.4 cents per dollar of reported dividend income. The individual's total tax bill is then recalculated for this expanded measure of income using the rules and rates of the new tax law. The difference between this enlarged tax bill and the baseline tax bill for 1988 is an estimate of the extent to which the baseline corporate tax reduces personal tax liabilities.

In the aggregate the $\$ 95$ billion corporation income tax reduces personal tax liabilities by $\$ 13.4$ billion. That is, without the corporate income tax, 1988 personal tax liabilities would be $\$ 13.4$ billion higher than with the baseline $\$ 95$ billion corporate tax.

Each individual's share of the $\$ 95$ billion corporate tax burden is calculated by attributing to the individual an imputed burden of 13.4 cents per dollar of real net interest income 19 and 59.4 cents per dollar of dividends. For this purpose, what matters is not the interest and dividends that individuals report for tax purposes but the actual amount of interest and dividends that they receive. Studies by the Department of Commerce (Park, 1986 ) indicate that individuals include in adjusted gross income only about 82 percent of the nominal interest income that they receive and about 71 percent of the dividends that they receive. The imputation therefore begins by grossing up dividends and nominal interest by dividing reported dividends by 0.71 and reported interest by 0.82 . The imputed burden of 59.4 cents per dollar of dividends is then calculated using this more accurate measure of true dividend income. Similarly the imputation of 13.4 cents per dollar of real net interest income is imputed on the basis of the real income estimated using the more accurate measure of total nominal interest income. 20 
In the aggregate, the amount of corporate tax imputed to individuals by the present method is $\$ 60.7$ billion or 64 percent of the total $\$ 95$ billion corporate tax liability. The remaining 36 percent is borne primarily by nontaxable owners of capital, by trusts and other fiduciary accounts, and by foreign investors.

Table 2 shows the distribution of these imputed changes in personal tax liabilities and total tax burdens. The individual tax returns in the TAXSIM mode 1 are weighted by the estimated 1988 weights and then grouped according to adjusted gross income under the rules of the new tax law. Column 1 shows the estimated number of returns in each category. Column 2 shows the average personal income tax liability at each income level under the new tax law. Column 3 shows the additional personal tax liability that would have been borne had the corporate income tax not reduced dividends and retained earnings. Column 4 shows the imputed tax burden that represents each individual's share of the $\$ 95$ billion tax on capital income.

Column 5 summarizes these impacts by showing the net effect of the corporate tax (column 4 minus column 3 ) as a percentage of the tax burden that would have existed in the absence of the corporate income tax (column 2 plus column 3). The numerator of column 5 is thus the unobserved tax burden on capital income caused by the corporate income tax minus the savings in personal taxes that result from the reduced dividends and capital gains. The denominator is the tax that would have been paid in the absence of the corporate tax, i.e., the sum of the actual personal tax and the reduction in personal taxes caused by the existing corporate tax. The result for the lowest income class is not shown because the percentage change is distorted by returns with tax liabilities near zero. 21 


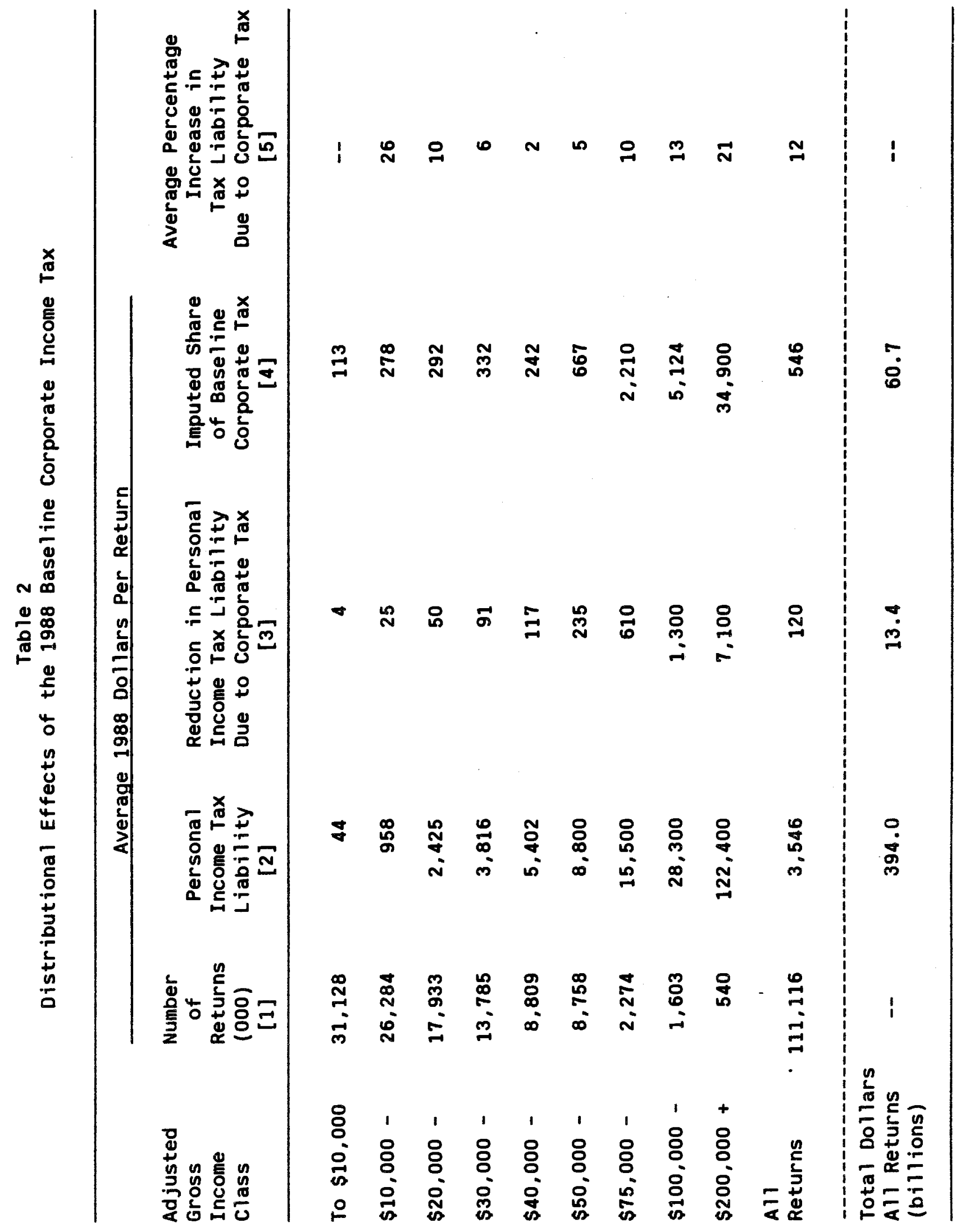


The impact of the corporate tax on individual tax burdens is relatively greatest among taxpayers in the lowest and highest income groups. The relatively substantial impact among higher income taxpayers is easy enough to understand since it is this group that holds the preponderance of corporate equity and fixed income securities. Among taxpayers with more than $\$ 200,000$ of 1988 income, the average personal tax liability is $\$ 122,400$ and the baseline corporate tax increases that liability by an average of $\$ 27,840$. The individual percentage increases in tax liabilities averaged 21 percent among this group of taxpayers. Even in the next two income groups, the corporate tax increased tax liabilities by more than 10 percent.

Middle income taxpayers have relatively little capital income and therefore experience only modest increases in tax liability because of the corporate income tax. The taxpayers with incomes between $\$ 30,000$ and $\$ 75,000$ have increases that averaged less than 5 percent of their personal tax liabilities.

Although the average corporate tax burden per taxpayer is smaller in the lower income groups, the percentage increase in the tax burden is greater because of the progressive character of the personal income tax. Indeed, the figures in Table 2 understate the relative increase in the tax burden among lower income taxpayers because the calculation of the percentage increases in column 5 excludes taxpayers with zero or negative individual income tax burdens. It is nevertheless striking that among taxpayers with incomes of $\$ 10,000$ to $\$ 20,000$ the corporate income tax raises the net tax burden per taxpayer by $\$ 278$ or 26 percent of the average personal tax liability of $\$ 958$. Among those with incomes less than $\$ 10,000$, the corporate tax burden averages \$113 or more than twice times the average individual income tax liability. 
The aggregate estimates shown in the last line of the table indicate that the corporate taxes imputed to individual tax returns totals $\$ 60.7$ billion or 64 percent of the $\$ 95$ billion to be allocated. The remainder is borne by foreign investors and nontaxable institutions since the portion borne by pension funds has been attributed back to shareholders.

\section{Imputing the Increase in Corporate Taxes}

A calculation similar to that of the previous section permits an analysis of who bears the increased corporate tax liability and how recognition of the corporate tax alters the measured distributional effects of the 1986 tax legislation.

The calculations presented in sections 4 and 5 imply that the $\$ 25$ billion increase in the 1988 corporate income tax has the following effects: First, it reduces dividends by 10.6 cents per dollar of dividends received by individual taxpayers and retained earnings by 11.6 cents per dollar of dividends received by individual taxpayers. Second, it implies an additional corporate tax liability of 14.7 cents per dollar of dividends and 4.1 cents per dollar of real interest income.

The reduction of dividends and retained earnings implies that the increase in the corporate tax liabilities reduces personal tax liabilities by $\$ 2.8$ billion. Taken by itself, this would imply that the tax package would not be revenue neutral if the $\$ 25$ billion of corporate income tax increase was matched by $\$ 25$ billion cut in personal tax revenue as conventionally calculated but would instead cause a revenue shortfall of $\$ 2.8$ billion.

Table 3 compares the distribution of the imputed changes in corporate tax liabilities with the predicted 1988 personal tax liabilities. These differ 


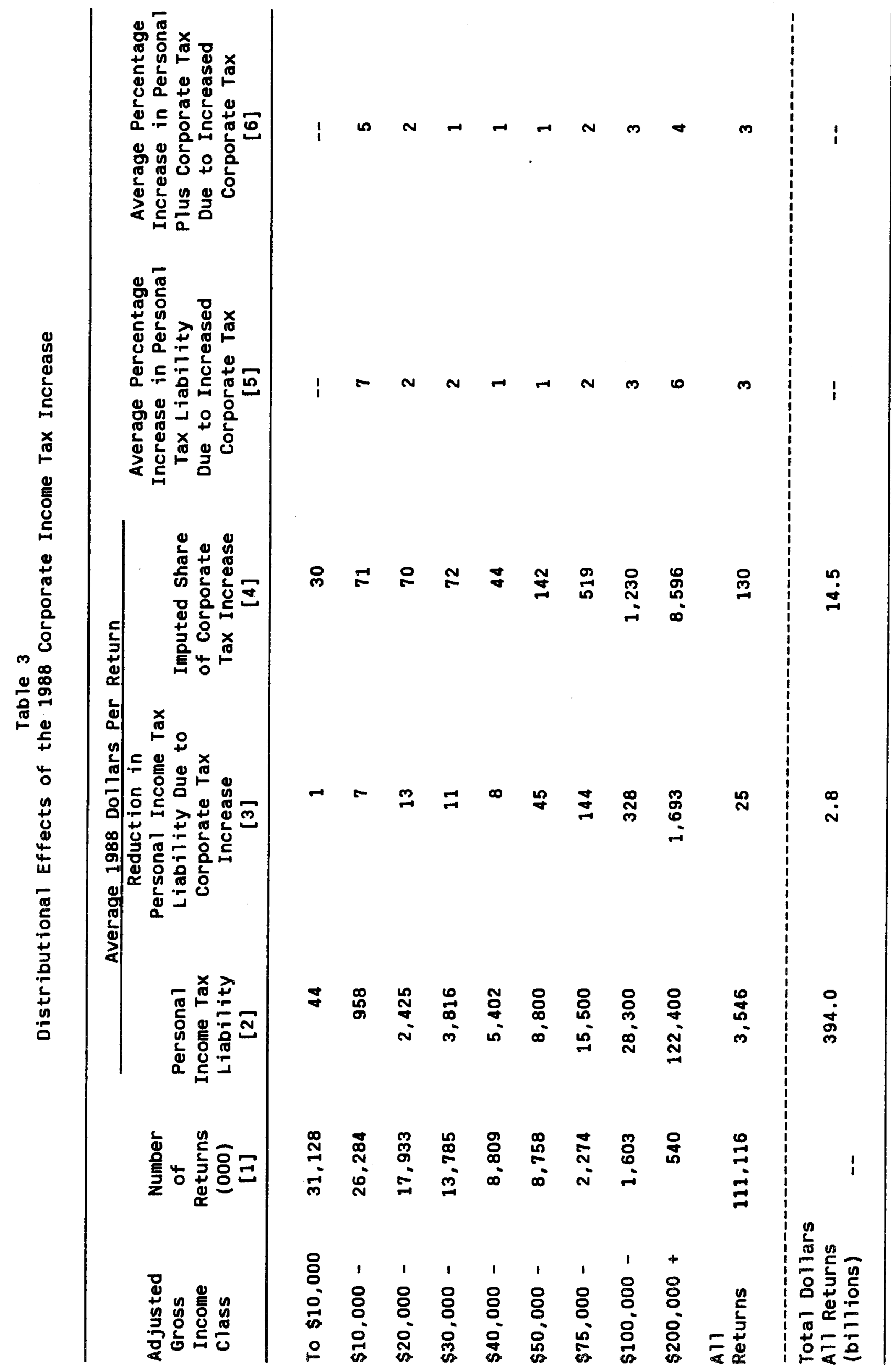


from those of Table 1 for several reasons: they are based on net post-tax capital income, they reflect the induced changes in dividends and retained earnings, etc.

Column 1 repeats the number of returns in each income class and column 2 repeats the projected 1988 personal tax liability at each income level based on the new personal income tax law but ignoring the effect of the change in corporate taxes. Column 3 shows the reduction in that personal tax liability that results from the decrease in dividends and retained earnings caused by the $\$ 25$ billion rise in corporate tax liabilities. This is calculated by reducing dividend income by 10.6 cents per dollar of received dividend income (and adjusting this amount for the average extent of underreporting) and reducing capital gains by one half of 11.6 cents per dollar of dividend iricome.

Column 4 shows the increase in the imputed tax burden that is caused by the $\$ 25$ billion rise in corporate taxes. This is calculated for each return as 5.6 cents per dollar of real net interest income received and 20.2 cents per dollar of dividend income received. The net impact of these two effects as a percentage of personal tax is reported in column 5 (i.e.., the average of the figures summarized in column 4 minus those of column 3 divided by column 2).

The corporate tax increase has only a small impact among middle income taxpayers but has a larger impact at both ends of the distribution. This pattern follows that of Table 2. Among top income taxpayers, the corporate tax change is equivalent to a 6 percent rise in personal tax liabilities, virtually the same as the proportionate tax increase among taxpayers with 
incomes between $\$ 10,000$ and $\$ 20,000$. In the lowest income group the increase in the corporate tax is almost as large as the remaining personal tax.

The figures in column 5 are a correct representation of the corporate tax increase as a percentage of the personal tax liability but not of the percentage increase in the individual's total tax liability. Column 6 therefore relates the extra tax due to the 1988 corporate tax increase to the combined personal and baseline corporate tax. The effect is to reduce the percentage increases due to the corporate tax (since the denominator is always larger) but not to change the overall implication of a substantial proportional tax increase with the largest increases at the top and bottom of the income distribution.

The present analysis also makes it possible to compare the conventionaliy estimated changes in personal tax liabilities with the estimated changes in total tax burdens that takes into account the changes in the corporate as well as the personal taxes. This is done in Table 4.

Column 2 of Table 4 shows the personal tax liability in 1988 under the "old law" (i.e., the law prevailing through December 1986). Column 3 presents the corresponding personal tax liability in 1988 under a fully phased-in specification of the "new law" as it would be conventionally calculated with no allowance for the effect of the change in the corporate tax. The fourth column shows the conventional average tax change at each income level, column 3 minus column 2. This is restated as a percentage of the "old law" tax liability in column 5 .

The total tax changes reported in the final row of the table show that the TAXSIM calculations imply that the fully phased-in 1986 changes in 


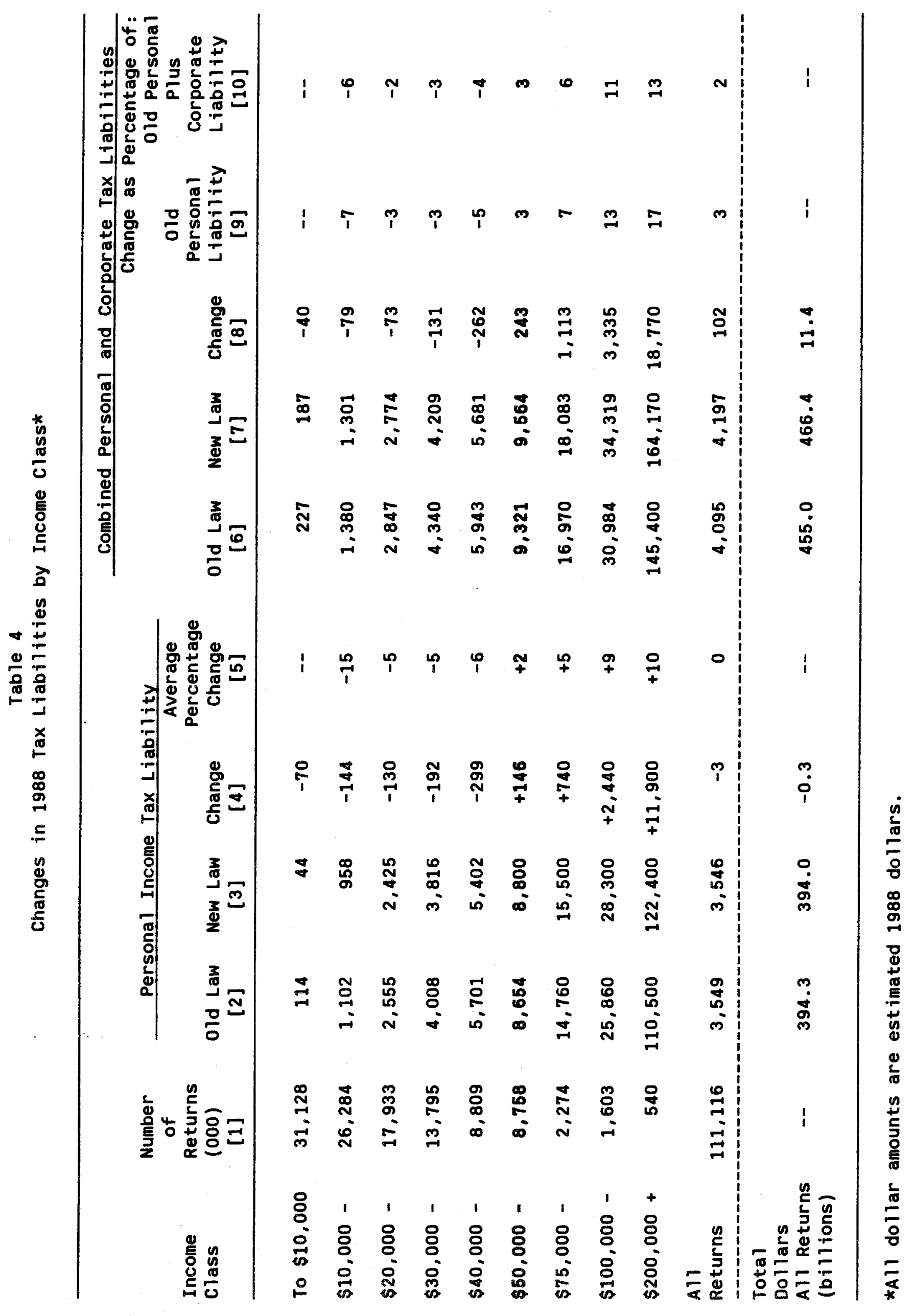


personal tax rules and rates reduces projected 1988 personal tax 1 iabilities by only $\$ 300$ million, nothing like the $\$ 25$ billion personal tax cut estimated by the staffs of the Treasury and the Joint Committee on Taxation. There are several possible reasons for this difference. A primary reason may be that the current TAXSIM estimates are based on the 1983 individual taxpayer file while the Treasury and Joint Committee estimates were based on individual tax returns for 1981. Between 1981 and 1983 individual taxpayer behavior was changed significantly as a result of the 1981 Economic Recovery Tax Act. Two important behavioral changes were the substantial increases in tax shelter activities and realized capital gains. By virtually eliminating such tax shelter activities and raising the tax rate on capital gains, the 1986 tax changes therefore represent a larger increase in potential tax revenue than would appear using the 1981 individual tax returns. Another possible source of the difference is that the government revenue estimates reflect unspecified behavioral changes attributable to the new tax rules. For example, individuals may be assumed to shift borrowing from nondeductible to deductible forms and to cut the realization of capital gains. Such behavioral changes, which would increase the effective tax cut implied by the 1986 legislation, are not reflected in the TAXSIM analysis. This may be particularly important since the TAXSIM calculations are based on a fully phased-in version of the new tax̀ law.

The proportional tax changes shown in column 5 indicate that the TAXSIM estimates are similar to the government projections for taxpayers with incomes under $\$ 50,000$ but then differ substantially. TAXSIM calculations imply that the average tax liabilities of taxpayers with incomes between $\$ 50,000$ and 
$\$ 75,000$ are essentially unchanged while the average tax liabilities of taxpayers with incomes over $\$ 75,000$ are actually increased. This is consistent with the explanation of the reasons for the aggregate differences discussed in the previous paragraph.

The substantial difference between the TAXSIM and government estimates of the tax reduction clearly deserves more attention than is possible in the current study. 22 The emphasis here will be on the difference between the estimated personal tax changes and the estimated changes when corporate as well as personal tax changes are imputed to individual tax returns.

Column 6 combines the personal tax under the "old law" from column 2 with the additional personal tax induced by the baseline corporate tax (column 4 of Table 2). Thus column 6 is the TAXSIM estimate of the total personal plus corporate tax under the "old law".

Column 7 is the corresponding estimate under the new law. It combines the individual income tax liability under the new law (column 3 ) with the baseline corporate tax (column 4 of Table 2 ) and the net change in the corporate tax (column 4 minus column 3 of Table 3 ).

The net change in the combined personal and corporate tax liabilities is reported in column 8 . For taxpayers with incomes up to $\$ 50,000$, the combined effect of the income tax change and the corporate tax change is a reduction in total tax liabilities. But for taxpayers with incomes over $\$ 50,000$, the average tax change in each income class is an increase. Column 9 expresses these changes as a percentage of the old personal tax liability and column 10 as a percentage of the combined personal plus baseline corporate tax liability. 
The figures in column 9 imply that the 1986 tax reform actually increased total tax liabilities of individuals in the top income class by 17 percent of the baseline personal tax liability. For those with incomes between $\$ 100,000$ and $\$ 200,000$, the average increase was 13 percent.

A comparison of columns 5 and 9 is perhaps the best indication of the effect of ignoring the corporate tax changes when evaluating the impact of the tax reform legislation. The tax reduction in the lowest income class is cut sharply, from the $\$ 70$ per return reduction in personal taxes to a combined reduction equal to only $\$ 40$ of the initial personal tax liability. Among those with incomes between $\$ 10,000$ and $\$ 20,000$, the tax reduction was cut in half. In the highest income group, recognizing the change in the corporate tax implies an additional tax increase equal to 6 percent of the initial personal tax liability. Among taxpayers with incomes between $\$ 100,000$ and $\$ 200,000$, recognizing the change in the corporate tax implies an additional tax increase equal to 4 percent of the initial personal tax liability.

Although a comparison of the figures in columns 5 and 9 is the best way to see the extent to which ignoring the corporate tax increases distorts the estimated tax change at each income level, the figures in column 9 are themselves an overstatement of the absolute change in the combined personal and corporate tax liabilities because the percentage change is based on the initial personal tax liability alone. Column 10 therefore presents the combined changes in the personal and corporate tax liabilities as a percentage of the initial level of the combined personal and corporate tax liabilities. These percentage changes are absolutely smaller than those of column 9 because the denominator is always larger. But even with this expanded base for 


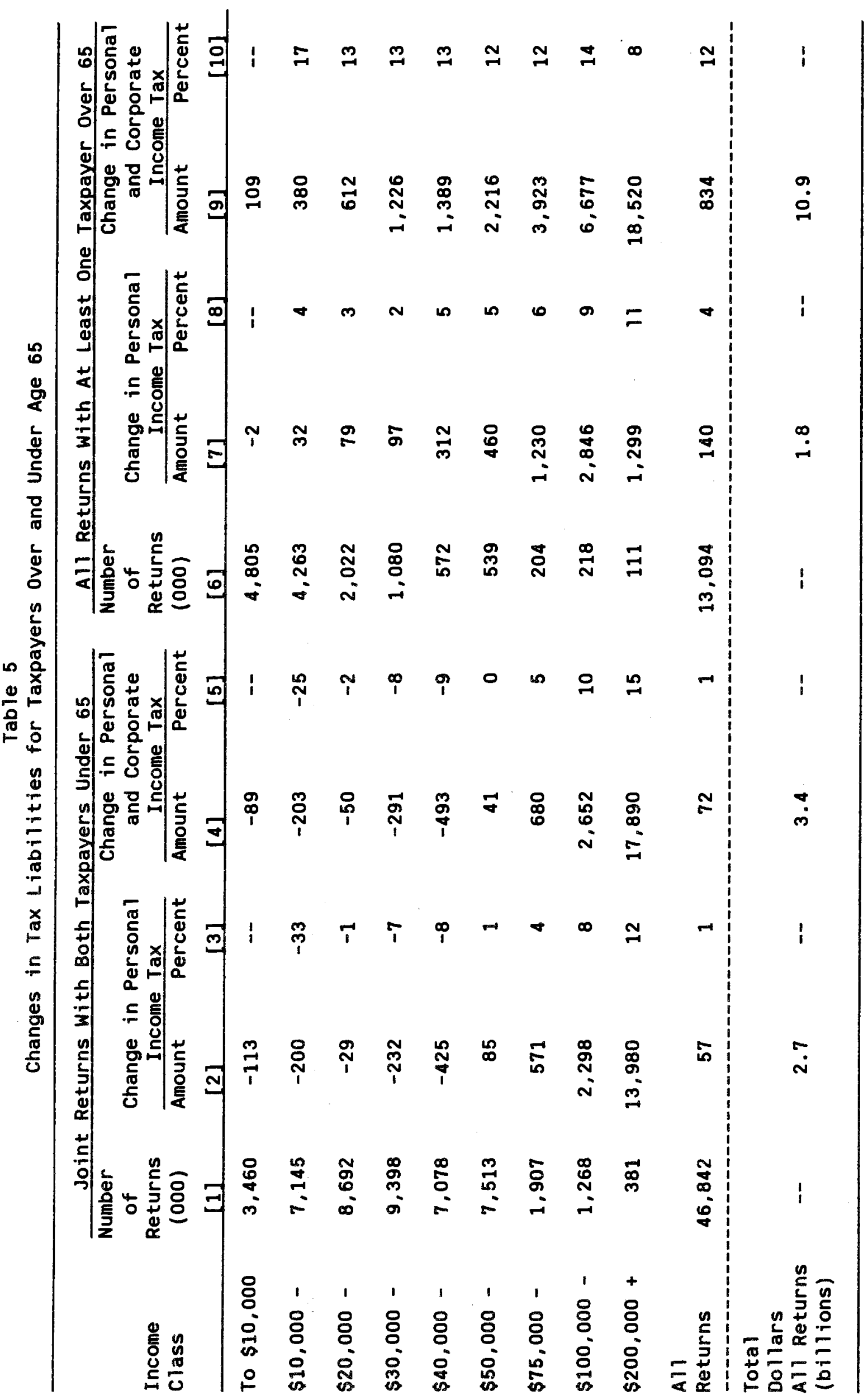


comparison, the top two income groups are seen to experience increases of 11 and 13 percent.

The importance of capital income among the lower income tax groups reflects the importance of older retired or partially retired individuals in these income classes. It is useful therefore to consider the analysis of the tax changes separately for older taxpayers and others. Table 5 presents data for two groups of taxpayers: the first group consists of married taxpayers filing join returns with neither individual over age 64 . The second group consists of all tax returns with at least one taxpayer age 65 and older.

For joint returns with both taxpayers under age 65 shown in columns 1 through 5 of Table 5 , the combined change in personal and corporate income taxes (column 5) is quite similar to the traditional change in the personal tax a lone (column 3). But for taxpayers over age 65, shown in columns 6 through 10, the two measures of the tax change differ dramatically.

Note first that even the traditional measure of the personal tax change indicates a tax increase for every income class except the very lowest one. This may reflect the absence of an increase in the personal exemption for those. over age 65 and the greater importance of capital gains in this age group. Although a more thorough analysis of the effects of the 1986 tax change by age and other demographic characteristics would clearly be desirable, it lies beyond the scope of this analysis. The emphasis here is on the contrast between the traditional change in the personal income tax (columns 7 and 8 ) and the change in the combined value of the personal and corporate income taxes (columns 9 and 10 ).

Column 10 shows that the total tax increase (the combination of the personal and corporate tax changes) is on average equivalent to a 12 percent 
rise in the personal income tax. The combined tax increase ranges from 17 percent in the $\$ 10,000$ to $\$ 20,000$ income group to 8 percent for taxpayers in the highest income group. The net effect of the corporate tax change alone is equivalent to an increase of about 8 percent of personal income tax liabilities.

\section{Conclusion}

This paper has presented a method of imputing to individual tax returns the net effect of changes in effective corporate tax rates. Particular attention is given to the difference between nominal and real capital income, to the problem of corporate pension funds and to the automatic effect of corporate tax changes on dividends and retained earnings. The analysis is limited, however, by the static equilibrium assumption, by the lack of a general portfolio framework of asset demand and by inadequate data on the real estate assets of individual taxpayers.

Application of this imputation method to the tax changes enacted in 1986 shows that the actual distribution of the total tax change was very different from the traditional distribution of only the personal income tax change. The net imputed corporate tax increase was equivalent to a $r$ ise of 6 percentage points in the personal income tax among taxpayers with 1988 incomes over $\$ 200,000$ and 4 percentage points among taxpayers with incomes between $\$ 100,000$ and $\$ 200,000$. The corporate income tax increase also added the equivalent of an 8 percent rise in the income tax for taxpayers with incomes between $\$ 10,000$ and $\$ 20,000$. By contrast, for middle income taxpayers (with incomes between $\$ 30,000$ and $\$ 75,000)$ the corporate tax increase was equivalent to an income 
tax rise of only 1 or 2 percent. The analysis shows that the higher corporate tax represents a particularly large increase for taxpayers over the age of 65 . Distributional considerations will continue to play a large role in the public and Congressional discussions of future tax reforms. The present study shows that it is very important to include the distributional consequences of corporate as well as personal tax changes in the analysis of any proposed tax reforms.

Cambridge, Massachusetts JuTy 1987 
same assets.

9. Unfortunately, no information is available on the individual taxpayers' implicit net rental income of owner occupied housing.

10. This is clearly true with respect to existing vested benefits. Benefits that accrue in the future may be modified to reflect the changed return on pension assets or wages may be adjusted. Eventually the tax on pension assets wi 11 be borne by labor but the transition period may last several decades. 11. Kotlikoff and Smith (1983) indicate that 75 percent of employer plan pension assets are in defined contribution plans. Total pension assets also include IRA, Keogh are $401 \mathrm{~K}$ plans.

12. This excludes the dividends and interest received by state and local pension plans since taxes borne by those plan assets inure to the detriment of the state and local governments and their taxpayers rather than to owners of corporate capital. It is not possible to impute that increase in the tax burden on state and local governments to individual taxpayers since on $1 y 30$ percent of the taxpayers itemize tax returns.

13. This includes the interest income and expenses of households and of pensions and other tax exempt entities.

14. Nontaxable state and local bonds are ignored in the present paper even though an increase in the tax on capital income would alter the interest rate on these securities since there is no information about them on individual tax returns.

15. Note that for the current analysis what matters is the ex post real interest rate and not the anticipated ex ante real rate.

16. The interest rates are the Federal Home Loan Bank Board series for new 
home mortgage yields.

17. Note that this is not equivalent to the household sector's inflationary loss on the value of its assets because household debt includes federal government bonds while corporate sector liabilities are net of assets that include government securities.

18. The method of estimating the market value of all outstanding corporate debt is an extension of the method used in Feldstein and Jun (1987) to estimate the value of the debt of the nonfinancial corporate sector. 19. As explained in Section 3 , real net interest income is calculated as the difference between 43 percent of nominal interest income and 67 percent of nominal interest expenses.

20. Note that a similar adjustment is not necessary for calculating the effect of the corporate tax on the personal tax liabilities since the effect on personal tax liabilities depends only on the amount of interest and dividends that the individual reports and not on the amount of interest and dividends that the individual actually receives.

21. The small number of tax returns that have a negative tax liability because of the rebatable earned income credit are ignored in calculating the percentage change.

22. Lawrence Lindsey is currently preparing an analysis of this problem. 23. The contrast between those under 65 and those over 65 also reflects the greater importance of mortgage debt anong those under 65. Since the corporate tax reduces real interest rates, it actually benefits those under age 65 . 


\section{References}

Ballentine, J. Gregory, "The Short-run Distributional Effect of Tax Reform" (1986), Tax Notes, June 9, 1986: 1035-39.

Bradford, David (1981), "The Incidence and Allocation Effects of a Tax on Corporate Distributions, Journal of Public Economics 15 (1): 1-22. Browning, Edgar and William Johnson (1979), The Distribution of the Tax

Burden. Washington, D.C.: American Enterprise Institute.

Executive Office of the President (1986), Midsession Review, August 1986.

Washington, D.C.: Executive Office of the President.

Feldstein, Martin (1970), "Corporate Taxation and Dividend Behavior," Review of Economic Studies.

Feldstein, M. and J. Jun (1987), "The Market Value of Corporate Debt and the Changing Debt-Capital Ratio," forthcoming.

Feldstein, Martin and Joel Slemrod (1980), "Personal Taxation, Portfolio Choice and the Effect of the Corporation Income Tax," Journal of . Political Economy 88 (5).

Feldstein, Martin, ed. (1983), Behavioural Simulation Methods in Tax Policy

Analysis. Chicago: University of Chicago Press.

Harberger, Arnold (1962), "The Incidence of the Corporation Income Tax," Journal of Political Economy 70: 215-40.

Kotlikoff, Laurence and Donald Smith (1983). Pensions and the American

Economy. Chicago: University of Chicago Press.

Kotlikoff, Laurence and Lawrence Summers (1986), "Tax Incidence." NBER Working Paper No. 1864, forthcoming in A. Auerbach and M. Feldstein, eds., Handbook of Public Economics, Vol. II. Amsterdam: North Holl land, 1987. 
Lindsey, Lawrence (1985), "Simulating the Response of Taxpayers to Changes in Tax Rates." Ph.D. Dissertation, Harvard University, Cambridge, Mass. Lintner, John (1956), "Distribution of Incomes of Corporations Among Dividends, Retained Earnings, and Taxes," American Economic Review 46: 97-113.

Musgrave, Richard and Peggy Musgrave (1980), Public Finance -- Theory and

Practice. New York: McGraw Hill.

0tt, Attiat and Ludwig Dittrich (1981), The Federal Tax Burden on Households. Washington, D.C.: American Enterprise Institute.

Park, Thai (1986), "Relationship Between Personal Income and Adjusted Gross Income: Revised Estimates, 1947-83," Survey of Current Business (May): $34-40$.

Pechman, Joseph (1985), who Paid the Taxes, 1966-85? Washington, D.C.: Brookings Institution.

Pechnan, Joseph and Benjamin Okner (1974), who Bears the Tax Burden? Washington, D.C.: Brookings Institution.

Shoven, John and John Whalley (1972), "General Equilibrium Calculation of the Effects of Differential Taxation of Income from Capital in the U.S.," Journal of Public Economics 1: 281-321.

Slemrod, Joel (1985), "A General Equilibrium Model of Taxation that Uses Micro-Unit Data with an Application to the Impact of Instituting a Flat Rate Income Tax," in John Piggot and John Whalley, New Developments in Applied General Equilibrium Analysis, Cambridge: Cambridge University Press. 